\title{
Counting the cost: COVID-19 school closures in South Africa and its impact on children
}

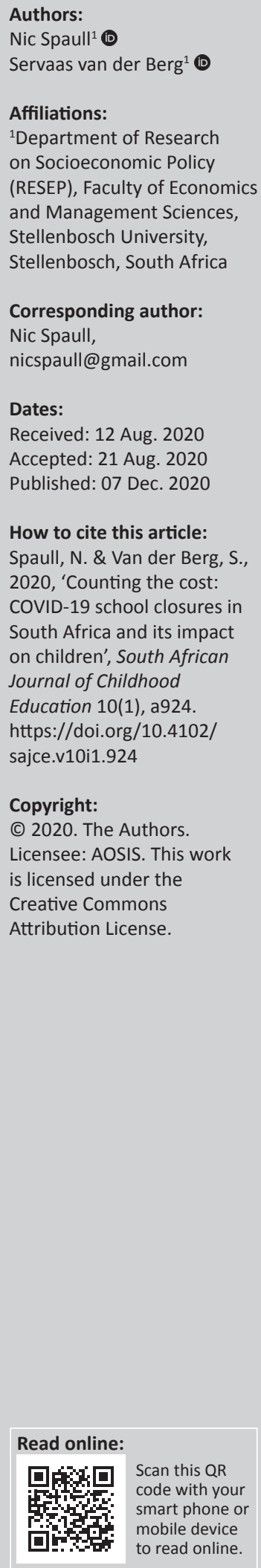

Background: When the new coronavirus rapidly spread across the globe, the impact of the virus on children was still unclear, and closing schools seemed the responsible thing to do. But much has been learnt since about coronavirus disease 2019 (COVID-19) and the effects of lockdown and school closures, both in South Africa and internationally.

Aim: It shows that the mortality risk of the virus is extremely small for children, even when assuming an extremely pessimistic scenario for total COVID-19 deaths.

Setting: We review the evidence at a national level in South Africa using nationallyrepresentative datasets.

Methods: This article offers evidence drawn from nationally representative household surveys, school surveys and administrative datasets, as well as research reports.

Results: International evidence predominantly shows that children are not important transmitters of this virus, which is different from the case for influenza, for example. We show that there are considerable costs to the lockdown for children. These relate to foregone leaning opportunities, mental health, nutrition and physical health.

Conclusion: We show that re-opening the economy whilst keeping schools closed results in many unintended consequences, including that children are at higher risk of being left home alone. Considering all of this, we propose that all children should return to schools, crèches and early childhood development (ECD)centres without any further delay.

Keywords: schooling and COVID-19; coronavirus; South Africa; school closures; socioeconomic impact of school closures.

\section{Introduction}

'In all matters concerning the care, protection and well-being of a child the standard that the child's best interest is of paramount importance, must be applied.'

\section{(The Children's Act [2005] Act Number 38 of 2005:34)}

Like most countries around the world, South Africa has experienced disruptions of unprecedented proportions as a result of the novel coronavirus Severe Acute Respiratory Syndrome Coronavirus 2 (SARS-CoV-2), commonly referred to as coronavirus disease 2019 (COVID-19). Following the World Health Organisation's (WHO) declaration of COVID-19 as a global pandemic, South Africa acted swiftly and severely to limit the spread of this virus. On 23 March 2020, the President announced that South Africa would enter a state of almost complete lockdown 3 days later on the 26th of March. At the time, there were 927 positive cases in the country and zero deaths.

What began as a 3-week lockdown period, morphed into an 8-week lockdown. That lockdown is still ongoing, now in its 5th month (August), albeit the newer levels of lockdown impose fewer restrictions. The 8-week hard lockdown included a ban on all public gatherings, closing all schools, and prohibiting all forms of physical commercial activity, except for the sale of food and medicine. The sale of alcohol and tobacco was banned. A national curfew was imposed prohibiting movement between 20:00 and 05:00. For the first time since apartheid, the army was deployed across the country with the intention of maintaining law and order and supporting the police. This included 70000 reserve soldiers who, at the time of writing, are still deployed across South Africa, largely in informal settlements. Even parliament was temporarily closed. Only the courts remained open out of fear that there would be no recourse to challenge government actions or to oppose the constitutionality of the measures being implemented. 
By and large, these containment measures were initially welcomed, or at the very least accepted, by the public, opposition parties and most scientific advisors. This is now starting to change. There are ongoing legal challenges (the Helen Suzman Foundation, Democratic Alliance) and growing scientific opposition to the way the government is handling the crisis (Mendelsohn et al. 2020; Van Bruwaene et al. 2020).

It is within this context that crèches and schools were also closed, temporarily re-opened for two grades (Grade 7 and 12) and subsequently closed again for all public schools for the month of August. For the 10 weeks of lockdown from the end of March up to the 8th of June, children were not allowed to go to school or see their friends and family outside of their house. During the first 5 weeks of 'hard' lockdown, children were not allowed to leave their homes for any reason except to seek medical attention.

As of 2 August 2020, the government's current plans (DBE 2020c) show that by the end of Term 2 (23 August 2020) South African children will have lost between 22\% and 65\% of the 'normal' school days scheduled up to that point. The reason for the range is that Grade 7 and 12 were treated differently to other grades and went back to school earlier. If there are no further school closures, Grade 12 children in public schools will lose 22 out of the 204 normal school days (11\%), Grade 7 will lose 27 days (13\%) and all other grades will lose 80 days (39\%). ${ }^{1}$

The aim of this article is to provide empirical evidence on how COVID-19, lockdown(s) and school closure(s) affect children $(<19$ years). We provide evidence on the age distribution of teachers and map these onto COVID-19 risk categories in the section 'Children, teachers and COVID-19 risk'. The following section 'School infrastructure, class sizes and social distancing in South Africa' presents evidence on school infrastructure and class-sizes in South Africa which are relevant for considerations around hygiene and the feasibility of social distancing. We then use household survey data to document the living situations of children and specifically how many children live with high-risk family members, and the employment status of their caregivers, in the section 'Household living situations'. The subsequent section 'Impacts of the lockdown(s) and school closure(s) on children' focuses on issues of malnutrition, depression, declining immunisations, indirect mortality from avoiding clinics, learning losses and impairment of young children's cognitive development as a result of lockdown(s) and school closure(s), to which should be added income losses and increased inequality. The penultimate section 'Home alone: The extent to which children

1.These numbers are using the Department of Basic Education's (DBE) revised calendar released on 2 August 2020; see also Appendix 1. Up until 23 August, calendar released on 2 August 2020; see also Appendix 1. Up until 23 August, schools would have had 136 days under the pre-COVID-19 timetable. In reality, Grade 7 and 12 had 106 and 101 days, respectively, and all other grades had 48 day (i.e. all other grades had no Term 2). Looking at the entire year, there would normally be 204 days in the school calendar, but the revised calendar shows 182 days for Grade 12, 177 days for Grade 7 and 124 days for all other grades. As a percentage of pre-COVID scheduled days, these amount to $11 \%$ lost for Grade 12 $13 \%$ lost for Grade 7 and $39 \%$ lost for all other grades. are left home alone when caregivers return to work and schools remain closed' reports the number of children left 'home alone' whilst the economy has re-opened and schools remain closed (i.e. those with no other caregivers except a working parent). Finally, the section 'Conclusion and policy recommendations' provides concluding comments and policy recommendations.

\section{Children, teachers and COVID-19 risk Age and COVID-19 risk in South Africa}

One of the primary findings emerging from the medical research around COVID-19 is that age and COVID-19 mortality risk are strongly correlated. That is to say that the risk of severe illness or death from COVID-19 is heavily concentrated amongst the older cohorts of the population. Figure 1 uses the most recent Western Cape data and reports the distribution of COVID-19 mortality by age. It shows that $80 \%$ of the 3069 people who died from COVID-19 in the Western Cape up until 01 August 2020 were 50 years or older, and that $56 \%$ were 60 years or older. The Western Cape was selected due to public data availability on the province's COVID-19 dashboard. However, media releases by the Gauteng Government (Mitchley 2020) report that $66 \%$ of the 1207 deaths in that province up to 29 July were aged 50 to 79 , showing an almost identical age breakdown to the Western Cape (the comparable figure in the Western Cape is 69\%). These age distributions of mortality are somewhat 'younger' than those seen in most high-income countries. For example, in the United States $81 \%$ of people who died from COVID-19 were 65 years or older (CDC 2020). See Our World in Data (2020) for case fatality rates by age for China, Italy, Spain and South Korea. In the earlier working paper version of this article (Van Der Berg \& Spaull 2020), we also compare the case fatality rate in the Western Cape and China and show that the average Chinese 55 year old infected with COVID-19 had a 1.3\% chance of dying, whilst the average 55 year old in the Western Cape infected with COVID-19 had a 4.9\% chance.

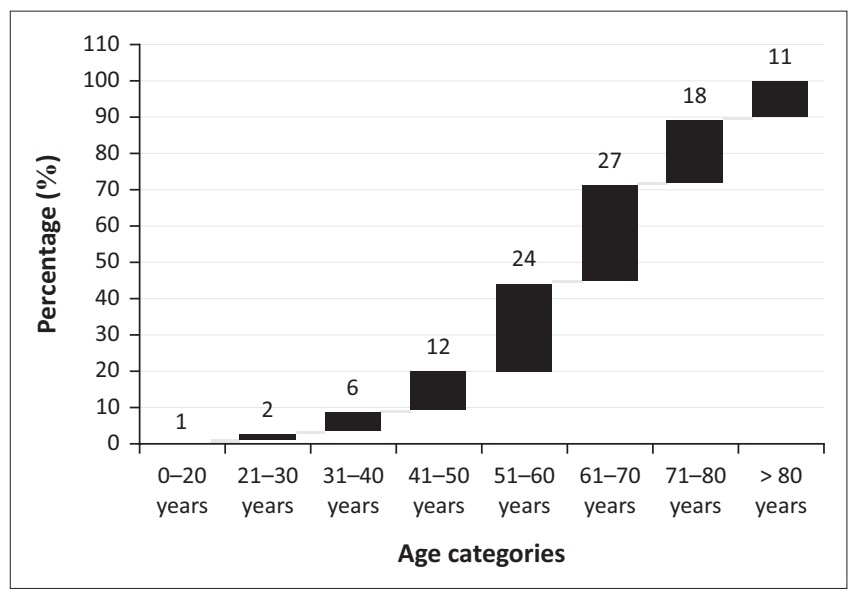

Source: Western Cape Government, 2020, Covid-19 Dashboard (Online), viewed 10 June 2020, from https://coronavirus.westerncape.gov.za/covid-19-dashboard

FIGURE 1: Distribution of COVID-19 deaths in the Western Cape by age category. Total deaths $=3069$. 


\begin{tabular}{|c|c|c|c|c|c|c|c|c|c|}
\hline Column & A & B & C & D & E & $\mathbf{F}$ & G & H & I \\
\hline $\begin{array}{l}\text { Age } \\
\text { category } \\
\text { (years) }\end{array}$ & $\begin{array}{l}\text { Population } \\
\text { in } 2016\end{array}$ & Deaths in 2016 & $\begin{array}{l}\text { \% died in } \\
2016\end{array}$ & $\begin{array}{l}\text { Normal probability } \\
\text { of dying is } 1 \text { in }\end{array}$ & $\begin{array}{l}\text { WC distribution } \\
\text { of deaths up to } \\
10 \text { June } 2020\end{array}$ & $\begin{array}{c}\text { Projections: } \\
\text { Projected SA } \\
\text { cOVID-19 deaths } \\
\text { in } 2020 \text { if } \\
\text { following WC } \\
\text { pattern }\end{array}$ & $\begin{array}{l}\text { Projections: } \\
\text { Probability } \\
\text { of dying of } \\
\text { COVID-19 in } \\
2020 \text { in } \\
\text { SA (\%) }\end{array}$ & $\begin{array}{l}\text { Projections: } \\
\text { Probability of dying } \\
\text { of COVID-19 in } 2020 \\
\text { in SA }\end{array}$ & $\begin{array}{l}\text { COVID-19 risk } \\
\text { categorisation } \\
\text { relative to regular } \\
\text { mortality risk }\end{array}$ \\
\hline $0-9$ & 11624007 & 9974 & 0.1 & 1 in 1000 chance & \multirow[t]{2}{*}{21} & \multirow[t]{2}{*}{328} & \multirow[t]{2}{*}{0.002} & \multirow[t]{2}{*}{1 in 66011 chance } & \multirow{2}{*}{$\begin{array}{l}\text { Practically } \\
\text { non-existent }\end{array}$} \\
\hline 10-19 & 10057108 & 9904 & 0.1 & 1 in 1000 chance & & & & & \\
\hline $20-29$ & 10822615 & 35917 & 0.3 & 1 in 333 chance & 56 & 876 & 0.008 & 1 in 12357 chance & \multirow[t]{4}{*}{ Very low } \\
\hline $30-39$ & 8540322 & 56763 & 0.7 & 1 in 143 chance & 185 & 2893 & 0.034 & 1 in 2952 chance & \\
\hline $40-49$ & 6085366 & 57925 & 1.0 & 1 in 100 chance & 360 & 5630 & 0.093 & 1 in 1081 chance & \\
\hline 50-59 & 4302071 & 65535 & 1.5 & 1 in 67 chance & 742 & 11605 & 0.270 & 1 in 371 chance & \\
\hline $60-69$ & 2739297 & 72056 & 2.6 & 1 in 39 chance & 817 & 12778 & 0.466 & 1 in 214 chance & Low \\
\hline 70-79 & 1320831 & 63628 & 4.8 & 1 in 21 chance & 561 & 8774 & 0.664 & 1 in 151 chance & Moderate \\
\hline $80+$ & 417248 & 63549 & 15.2 & 1 in 7 chance & 327 & 5114 & 1.226 & 1 in 82 chance & High \\
\hline Total & 55908865 & 435251 & 0.8 & 1 in 129 chance & 3069 & 48000 & 0.086 & 1 in 1165 chance & Low \\
\hline Source & $\begin{array}{l}\text { (StatsSA, } \\
\text { 2016b:9) }\end{array}$ & $\begin{array}{l}\text { (StatsSA, 2018c:8). } \\
\text { Infant deaths } \\
\text { (age } 0 \text { years) are } \\
\text { excluded }\end{array}$ & $\begin{array}{c}\text { Calculated } \\
\text { as B/A }\end{array}$ & $\begin{array}{l}\text { Calculated } \\
\text { as 100/C }\end{array}$ & $\begin{array}{l}\text { WC COVID-19 } \\
\text { Dashboard } \\
1 \text { August } 2020\end{array}$ & $\begin{array}{l}\text { Apportioning ASA, } \\
\text { SAMRC \& Deloitte } \\
2020 \text { total } \\
\text { projected deaths } \\
\text { conservative } \\
\text { estimate }(48000) \\
\text { across age } \\
\text { distribution }\end{array}$ & $\begin{array}{l}\text { Calculated } \\
\text { as F/A }\end{array}$ & $\begin{array}{l}\text { Column G reported } \\
\text { as chance }(1 / G)\end{array}$ & $\begin{array}{l}\text { Comparing } \\
\text { column H and } \\
\text { column D }\end{array}$ \\
\hline
\end{tabular}

WC, Western Cape; COVID-19, coronavirus disease 2019.

FIGURE 2: Comparing risk of death in a regular year and risk of death from COVID-19 infection by age.

Contextualising COVID-19 mortality risk relative to 'normal' mortality risk is worth the effort. That is to say that in a regular year people that are older also have a higher probability of dying from non-COVID-19 causes. Comparing COVID-19 mortality risk to 'normal' mortality risk is also helpful to put the relative risk of death in terms that are understandable. Figure 2 reports Statistics South Africa's mid-year population estimates for 2016 (StatsSA 2016b:9) as well as deaths for the same year (StatsSA 2018c:8) by age category. They show that a typical 45 year old in South Africa had a 1 in 100 chance of dying in 2016 from 'regular' (i.e. non-COVID-19) causes. It is clear that regular mortality risk is also strongly associated with age, as one would expect. Given that South Africa has not yet experienced peak infections or deaths from COVID-19, in order to compare annual risk of death (from 2016) to COVID-19 risk of death in 2020, one needs to make assumptions about the total number of deaths from COVID-19 in 2020 in South Africa.

The Department of Health has consulted numerous modelling experts to predict the total number of infections and deaths from COVID-19, as this is important information needed for planning and preparation. Reviewing the projections put forward by the Actuarial Society of South Africa (ASA 2020:4), the South African COVID-19 Modelling Consortium (SACMC) and Deloitte indicate that the highest possible estimates of COVID-19 deaths in South Africa could be as high as $40000-48000$ deaths by the end of 2020 (Child 2020; Davis 2020). These are also the projections that have been cited by the Minister of Health. (It should be noted that at the time of writing (02 August 2020), there have been only 8153 COVID-19 deaths in the country.) Taking a conservative approach and using these upper-bound projections of
COVID-19 deaths in South Africa in 2020 (48 000), we use the distribution of deaths by age in the Western Cape (column E) to apportion the 48000 total deaths across the different age categories. (Note, this is the age distribution of deaths in the Western Cape for the first 3069 deaths, i.e. up to 01 August 2020.) For example, if the 48000 deaths follow the Western Cape distribution of COVID-19 deaths then there will be 12778 deaths amongst the 60-69 year age group. This table allows one to ask, 'What is the probability that someone in a particular age category is going to die from COVID-19 in 2020 in South Africa?' It shows that for those under 70 the risk of death from COVID-19 is exceedingly small. For example, the average 45 year-old has a 1 in 1081 chance of dying of COVID-19 in 2020. A 45 year-old's regular mortality risk in 2016 was 1 in 100.

Whilst it is true that these projections depend on the assumption of 48000 COVID-19 deaths in South Africa in 2020, there are very few specialists who believe that the figure will be higher than this. Furthermore, even if COVID-19 deaths were twice as large (96 000) as predicted here (which would halve the chance numbers in column $\mathrm{H}$ ), the risk of death from regular causes for all age groups would still drastically outweigh the risk of death from COVID-19 multiple times over. It is for this reason that the risk categorisation in column I, which reports the relative risk of COVID-19 mortality and regular mortality, indicates that for the population at large under 70 years of age, the risk of death from COVID-19 is low or very low when compared to regular mortality risk. Put differently, people should be far more worried about dying of regular causes than from COVID-19. This does not, however, indicate that sensible precautions such as social distancing or wearing a mask should be ignored. 
The above discussion has important implications for school closures, as these measures are justified partly on the basis that they will prevent the healthcare system becoming overwhelmed, but also because of the greater mortality risk to teachers. Yet if the assumptions underlying the above data are correct, the additional mortality risk to teachers and caregivers up to age 70 is low relative to the normal mortality risk that they face. For children the risk is exceedingly small. Professor David Spiegelhalter at Cambridge University analysed COVID-19 mortality data in the United Kingdom and concluded that 'In school kids aged five to 15 it's not only a tiny risk, it's a tiny proportion of the normal risk'. He went on to say that the risk was so low that children were more likely to get struck by lightning (a chance of 1 in 1.7-million) than die of COVID-19 (1 in 3.5-million) (Spiegelhalter 2020).

The evidence emerging from South Africa on children's COVID-19 risk of severe illness is completely congruent with international research showing that children do not get severely ill from COVID-19. There are so few recorded deaths of children from COVID-19 that it is difficult to draw any conclusions (see Spaull 2020 for an overview of the epidemiological research on this). The South African Paediatric Association (SAPA) in their statement on COVID-19 (SAPA 2020) explain that:

Children biologically contain SARS-CoV-2 better than adults, are less likely to get sick if infected, have milder disease, are unlikely to die from COVID-19, and are probably less infectious than adults.

Whilst there are occasional articles internationally challenging the consensus on particular areas (such as that children are as infectious as adults or that schools are sites of rapid spread), these articles cannot be seen in isolation. As there is now a large number of reputable articles showing evidence that children are far less affected by COVID-19 than adults, we regard this as much stronger evidence than a small number of articles that show contrary findings. Whilst competing evidence should not be dismissed, it must be synthesised. See Boast, Munro and Goldstein (2020) for an excellent (and continually updated) synthesis of the evidence by paediatric epidemiologists.

Very recent data from the two provinces that experienced their COVID-19 surge first show that approximately $0.8 \%$ of teachers tested positive - interestingly this is the exact same figure in Gauteng (Gustafsson 2020a) and the Western Cape (Schäfer 2020). Thus, Gustafsson (2020a) concludes that 'The percentage of educators who were found to be infected ... is not different to estimates for demographically similar people in the Gauteng population as a whole' (p. 1). Whilst it is plausible that there is under-reporting of COVID-19 cases amongst teachers and students, this is also likely to be the case amongst those in the general public or working in other industries. Two other findings are also noteworthy:

(1) Cases as a percentage of everyone is [sic] nine times higher for educators than for the learners who attended school. This is what one might expect, given the medical evidence on lower levels of morbidity, but even infection, among younger children. (Gustafsson 2020a:1-2)

(2) There is very little evidence of clusters or 'outbreaks' of infections; of the 709 schools in the dataset whilst 505 had at least one educator case, $69 \%$ reported just one case for the entire period, and $96 \%$ reported no more than three cases ... [there is] no evidence of clustering of schools with infections in specific geographic areas. (Gustafsson 2020a:1-2)

Similar trends are seen in the Western Cape (Schäfer 2020), although that analysis is not as sophisticated or detailed. Clearly the evidence that exists on school-level cases indicates that teachers are not at higher risk compared to the rest of the public, and where schools were open and students were attending school (in the Western Cape and Gauteng) there is no evidence of outbreaks amongst either students or teachers.

\section{The age distribution of learners and teachers in South Africa}

Although it is clear that the additional mortality risk posed by COVID-19 is small relative to regular mortality risk, it is nevertheless true that this additional risk is related to age. Therefore, we report the age distributions of both learners and teachers in South Africa with the aim of identifying the number and percentage of teachers in higher risk age categories. To do so, we use data from the Education Management Information System for learner age (DBE 2013) and government payroll data for teacher age (PERSAL, own 2020 projections based on 2017 data).

For learners we report the age range of the 10th to the 90th percentile per grade, whilst for teachers we order the distribution by age from youngest to oldest and create 10 equal deciles of age (Figure 3). For example, in Grade

\begin{tabular}{|c|c|c|c|c|c|c|}
\hline \multicolumn{3}{|c|}{$\begin{array}{l}\text { Distribution of learner age in years } \\
\text { (EMIS) }\end{array}$} & \multicolumn{4}{|c|}{$\begin{array}{l}\text { Distribution of teacher age in years } \\
\text { (PERSAL) }\end{array}$} \\
\hline & $\begin{array}{l}\text { 10th } \\
\text { percentile }\end{array}$ & $\begin{array}{c}\text { 90th } \\
\text { percenti }\end{array}$ & & & Youngest & Oldest \\
\hline $\begin{array}{l}\text { Learner Grade } 1 \\
\text { age by } \\
\text { grade }\end{array}$ & 6 & 8 & $\begin{array}{l}\text { Deciles of } \\
\text { teacher age } \\
\text { (youngest }\end{array}$ & $\begin{array}{l}\text { Decile } 1 \\
\text { (youngest } \\
10 \% \text { ) }\end{array}$ & 22 & 29 \\
\hline Grade 2 & 7 & 9 & to oldest) & Decile 2 & 29 & 33 \\
\hline Grade 3 & 8 & 10 & & Decile 3 & 33 & 39 \\
\hline Grade 4 & 9 & 12 & & Decile 4 & 39 & 45 \\
\hline Grade 5 & 10 & 13 & & Decile 5 & 45 & 48 \\
\hline Grade 6 & 11 & 14 & & Decile 6 & 48 & 51 \\
\hline Grade 7 & 12 & 15 & & Decile 7 & 51 & 53 \\
\hline Grade 8 & 13 & 17 & & Decile 8 & 53 & 55 \\
\hline Grade 9 & 14 & 18 & & Decile 9 & 55 & 58 \\
\hline Grade 10 & 15 & 20 & & $\begin{array}{l}\text { Decile } 10 \\
\text { (oldest } \\
10 \% \text { ) }\end{array}$ & 58 & 65 \\
\hline Grade 11 & 16 & 21 & & & & \\
\hline Grade 12 & 17 & 21 & & & & \\
\hline
\end{tabular}

EMIS, Education management information system; PERSAL, personnel and salary system. FIGURE 3: The distribution of learner age range (10th-90th percentile) by grade, and teacher age by decile in South Africa. 


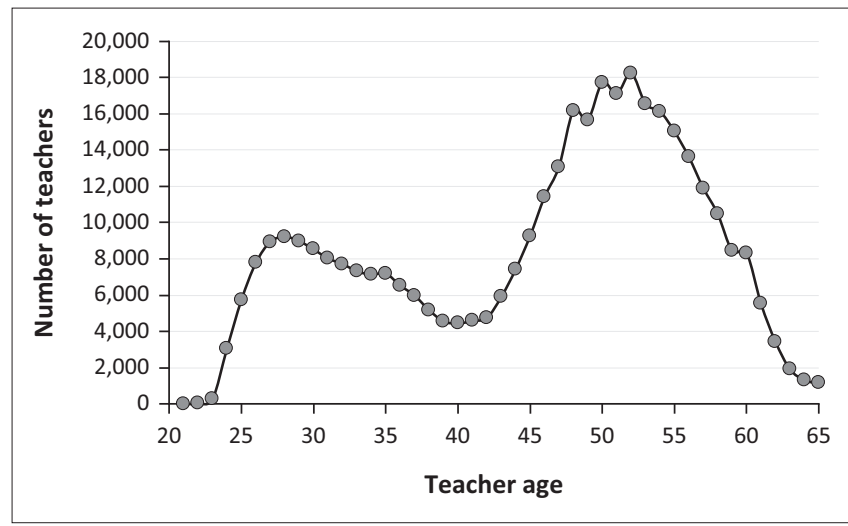

FIGURE 4: Projected teacher age in South Africa, 2020.

12 there are $10 \%$ of learners who are younger than 17 (10th percentile) and $90 \%$ of learners who are under the age of 21 (90th percentile). Given that those under the age of 60 are at low risk of severe illness and death from COVID-19, of most interest for the present purposes is the finding that $10 \%$ of teachers are aged $58-65$ years old (10th decile). There are approximately 380000 teachers in the system, so approximately 38000 are aged 58-65 years (see also Figure 4).

\section{What percentage of teachers have comorbidities?}

In addition to age, international research has shown that individuals with certain comorbidities are at higher risk of COVID-19 mortality. The (WHO 2020a) reports that

[E]vidence to date suggests that two groups of people are at a higher risk of getting severe COVID-19 disease. These are older people (that is people over 60 years old); and those with underlying medical conditions (such as cardiovascular disease, diabetes, chronic respiratory disease, and cancer. (p. 2).

Of the 1836 COVID-19 deaths in Gauteng up to 29 July, 57\% had either diabetes or hypertension, or both (Mitchley 2020). Similarly, the Western Cape Department of Health (2020) reports that of 2182 COVID-19 deaths amongst those aged 20 and older, 1042 people had diabetes (48\%) and 1086 had hypertension $(50 \%)$ - these percentages are not mutually exclusive, since someone can have both.

There is currently no nationally representative data on the comorbidities of teachers specifically. However, nationally, approximately $13 \%$ of South Africans aged 20-79 are estimated to have diabetes, according to the International Diabetes Federation (2019). Applying the ratio of teachers to the national population in this age group, there could be perhaps around 47500 teachers who have diabetes, or one in every eight teachers. Cardiovascular disease is a major source of mortality in South Africa, often associated with hypertension. These diseases increase an individual's COVID-19 mortality risk. However, it should be noted that the mortality total provided in Figure 2 is a national figure and already includes deaths associated with these and other comorbidities. An unpublished report on teacher comorbidities based on a survey conducted by teacher unions found that $50 \%$ of respondents had at least one comorbidity (Mthethwa 2020). By contrast, the Director General, Mr Mweli, reported to Parliament on 30 June that about $6 \%$ of teachers (20 140 teachers) had applied for a concession to stay at home given that they had comorbidities (Mthethwa 2020).

\section{School infrastructure, class sizes and social distancing in South Africa}

Whilst there are numerous ways to limit the spread of COVID-19, the three preventative measures that receive the most attention are (1) washing hands with soap and water or alcohol-based sanitiser, (2) wearing masks and (3) practising social distancing. At the most elementary level, the first of these requires soap and water and the last requires space. To what extent are these available in South African schools? In this section, we look at data from the School Monitoring Survey (SMS) of 2017 to report what percentage of primary schools and high schools in South Africa have access to running water, and what is the distribution of class sizes in the country.

\section{Access to running water}

The SMS data show that in 2017 nationally $74 \%$ of primary schools and $80 \%$ of secondary schools report access to running water (DBE 2018:80). However, there is considerable provincial variation in access to this most basic resource. Lack of access to running water is especially acute in KwaZulu-Natal, where only $53 \%$ of primary schools and $59 \%$ of secondary schools report access. In contrast, approximately 95\% of primary schools and high schools in Gauteng and the Western Cape have running water (DBE 2018:81). Without access to running water, how are children and teachers expected to wash their hands? Thus, special measures had to be instituted. Coronavirus disease 2019 is an opportunity for South Africans to reflect and acknowledge that in 25 years of democracy we have not managed to provide all schools with basic infrastructure like running water, electricity and safe toilet facilities. ${ }^{2}$ The fact that a quarter of primary schools do not have access to running water in a middle-income country like South Africa is an indictment and an ongoing source of shame. Whilst this is clearly a pre-requisite for basic hygiene during a pandemic, it is also a pre-requisite for basic dignity in everyday life.

Due to teacher union opposition about returning to schools that have no running water and therefore limited ability to practice personal hygiene, the Department of Basic Education (DBE) went into overdrive to provide schools with water tanks so that teachers would return. On the 7 th of June, the Minister announced that $95 \%$ of schools now had running

2.The SMS data show that nationally $12 \%$ of primary schools and $6 \%$ of high schools do not have ectrity, do not have electricity, whilst 21\% of primary schools and 16\% of high schools do not have adequate toils (DBE 2020. p.80). Provinces with the greatest needs are Limpopo, KwaZulu-Natal, the Eastern Cape and the Free State. Note that the SMS sample is nationally representative and includes 1000 primary schools and 1000 secondary schools (DBE 2018: p.11). 
water (Motshekga 2020). This was accomplished through a contract with Rand Water to provide water tanks to 3500 schools (Motshekga 2020):

The support provided by the Department of Water and Sanitation, Rand Water, the Department of Health, National Treasury; and the recent involvement of the South African National Defence, the Development Bank of Southern Africa (DBSA), the Department of Transport, and Mvula Trust is second to none. Their involvement has accelerated our interventions in the provinces, especially the reach to the most rural and remote schools. (Motshekga 2020:1)

This is a commendable achievement, and may yet be one of the few positive outcomes of the pandemic. It is truly remarkable that in the space of 6 weeks the DBE has managed to do what it was unable to do in the last 20 years.

\section{Class sizes and the feasibility of social distancing}

In addition to information on school infrastructure, the SMS also asked teachers about the class size of the largest class ${ }^{3}$ that they taught. This was asked of teachers in Grades 3, 6, 9 and 12. The graph in Figure 3 reports the distribution of class sizes in South African primary schools split by quintiles of school wealth (Q1 is poorest, Q5 is richest). It shows that nationally $63 \%$ of primary school children are in classes of 40 or more learners per class, with $16 \%$ in classes of 60 or more per class. In the report version of this article (Van Der Berg \& Spaull 2020), we also report these statistics for secondary schools and by province, as well as corroborating evidence on class sizes from Trends in International Mathematics and Science Study (TIMSS), Progress in International reading Literacy Study (PIRLS) and Southern and Eastern African Consortium for Monitoring Educational Quality (SACMEQ).

The DBE's draft 'National Minimum Norms and Standards for School Infrastructure' document reports architectural norms that must be followed when building classrooms. Page 91 of these norms states that the maximum class size that should be considered is 40 learners per class (SA Government 2008:91). As a result, virtually all South African classrooms are built to accommodate 40 learners. The norms further specify sitting spaces of 1.2 to 1.5 square metres for each child (SA Government 2008:91). If a class had 40 learners in it, then social distancing within the classroom in accordance with the WHO guidelines (WHO 2020) would be possible.

Reviewing the data on class sizes in South Africa (Figure 5) in conjunction with government regulations and the spatial realities of South African classrooms, it is clear that at least half of South African learners will not be able to practice social distancing within a classroom. Teaching outdoors is one possible option, but this is also logistically difficult in most cases.

Given that COVID-19 mortality risk is very low compared to regular mortality risk (Figure 2), and virtually non-existent

3.It is only in Grade 3 that we also have the observed class sizes in SM 9 and 12), in addition to the question on largest class taught. However, it is reassuring to note that the observed and self-reported class sizes are not very dissimilar. Thanks to Tim Kohler for help with this.

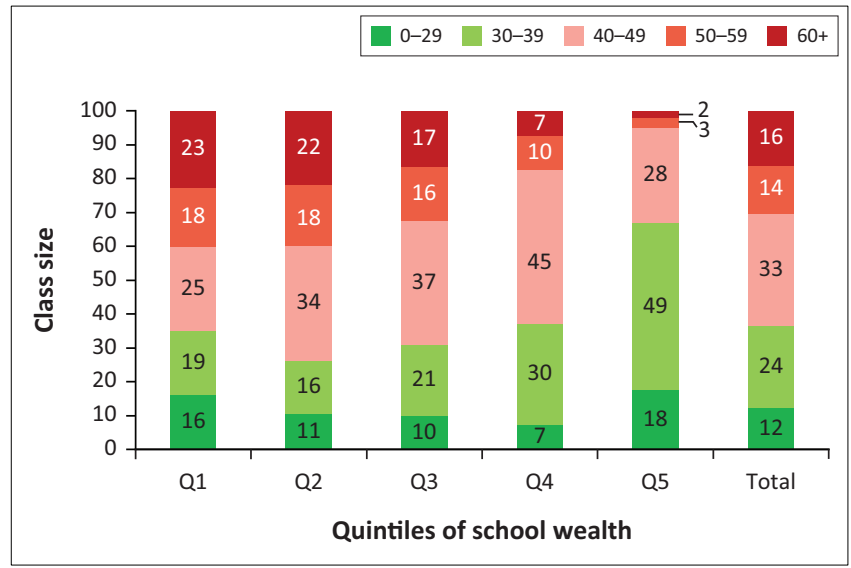

FIGURE 5: Distribution of largest class taught by Grade 3 and 6 teachers in South African primary schools by school wealth quintile.

for children, we believe the DBE should acknowledge that it is not feasible for about half of South African schools to practice social distancing within the classroom. Whilst it should require mask-wearing for older children and social distancing on the playground, full social distancing within the classroom is simply not realistic. A similar situation even applies to a rich country like Germany, where all children are returning to school in the autumn term without attempting to maintain full social distancing in classrooms, for as the Berlin Education Senator puts it, 'Everyone who is familiar with schools knows it's unrealistic to start up regular operations with 1.5-meter social distancing rules' (KCRW 2020). Desks should be spaced out as much as possible, and timetabling arrangements to facilitate social distancing should be implemented. But attempts to implement full social distancing in all classrooms are futile in our context and are likely to unnecessarily further disrupt teaching and learning, to the detriment of children.

\section{Household living situations}

Thanks to Statistics South Africa and other surveys and an active research community, we know a lot about the often dire social and economic conditions that many children still find themselves in today (Table 1). We know that poverty has declined since the political transition, and so has one of its worst manifestations such as child hunger - but they have not been eliminated. According to the Community Survey of 2016, exactly one-third of children were still in households that had an income below the food poverty line, where not even minimum food needs can be met, and just over twothirds $(67 \%)$ were below the higher, but still frugal, upperbased poverty line, the level of income required to meet most basic needs (StatsSA 2016a). Thanks to the expansion of the Child Support Grant, these child poverty rates have been declining over a large part of the post-transition period, but even in 2018, parents indicated that 2.5 million children (13\% of children) sometimes go hungry. Anthropometric indicators of nutritional status in the Demographic and Health Survey (DHS) indicate that stunting (low height for age, an indicator of long term nutrition and health status) was still prevalent in $27 \%$ of children under 5 in 2016 . Wasting (low weight 
TABLE 1: Children who live in households with no employed adults, who experience hunger or who live in areas where crime prevents them from using parks, 2018.

\begin{tabular}{|c|c|c|c|c|c|c|}
\hline Region & $\begin{array}{l}\text { Child population } \\
2018\left({ }^{\prime} 000\right)\end{array}$ & $\begin{array}{l}\text { Children living in } \\
\text { households without an } \\
\text { employed adult (\%) }\end{array}$ & $\begin{array}{l}\text { Children experiencing } \\
\text { hunger ('000) }\end{array}$ & $\begin{array}{l}\text { Children experiencing } \\
\text { hunger }(\%)\end{array}$ & $\begin{array}{c}\text { Children in public schools } \\
\text { who benefit from school } \\
\text { feeding }(\%)\end{array}$ & $\begin{array}{l}\text { Areas where fear of crime } \\
\text { prevents children from } \\
\text { going to parks }(\%)\end{array}$ \\
\hline Western Cape & 1971 & 8 & 288 & 15 & 54 & 47 \\
\hline Eastern Cape & 2514 & 46 & 212 & 9 & 90 & 38 \\
\hline Northern Cape & 436 & 29 & 73 & 17 & 83 & 57 \\
\hline Free State & 1021 & 35 & 131 & 13 & 80 & 35 \\
\hline KwaZulu-Natal & 4184 & 36 & 826 & 20 & 84 & 28 \\
\hline Gauteng & 4186 & 15 & 345 & 8 & 55 & 46 \\
\hline Mpumalanga & 1673 & 29 & 222 & 13 & 88 & 39 \\
\hline Limpopo & 2374 & 41 & 118 & 5 & 91 & 15 \\
\hline Total & 19741 & 30 & 2500 & 13 & 77 & 35 \\
\hline
\end{tabular}

Source: Hall, K., 2019, 'Income poverty, unemployment and social grants', in M. Shung-King, L. Lake, D. Sanders \& M. Hendricks (eds.), South African Child Gauge 2019, Children's Institute, University of Cape Town, Cape Town; Statistics South Africa, 2018a, Marginalised groups indicator report 2018, StatsSA, Pretoria; Statistics South Africa, 2019a, General household survey 2018, StatsSA, Pretoria; Statistics Sount Africa, 2019c, Victims of crime survey 2018/19, StatsSA, Pretoria.

for height), a measure of shorter term nutritional adequacy, was less common at less than 3\% (National Department of Health et al. 2019). In the context of COVID-19, it is especially concerning that school closures and the lockdown are likely to have significantly exacerbated child hunger - because of job and income losses, but also because children are not receiving free school meals. In 2018, $77 \%$ of children in public schools, approximately 9 million children, received a school meal every school day (Statistics South Africa 2019a). This is an important source of food that would have fallen away during the lockdown and school closures. Even though malnutrition is not often stated as the cause of death in South Africa, it often remains an important contributor. Child mortality audits show that almost a third of children who die are severely malnourished (Bamford et al. 2018).

\section{Households}

It is perhaps helpful to provide some context as to the types of households that children find themselves in. Altogether $62 \%$ of South African children, and three-quarters of those in rural areas, live in extended families. Less than one-third of children live in households where both parents are present, and almost $42 \%$ live in households where the mother is the only parent present (StatsSA 2020a). Only 13\% of children are in households with medical aid, 32\% live in households without potable water and almost $20 \%$ in homes without sanitation (Statistics South Africa 2018a). Given that COVID-19 risk is strongly associated with age, it is also worth noting that the Community Survey of 2016 shows 15\% - 20\% of learners aged 5 to 20 live with someone aged 65 or older in the household.

\section{Stimulation}

Although almost half (49\%) of children aged 0 to 4 stay at home with parents or guardians, research shows a worrying lack of stimulation for many children. Only $53 \%$ of parents or guardians report reading books with children, 57\% report colouring or drawing with them and $65 \%$ report telling stories (Statistics South Africa 2019a). For those without these forms of stimulation at home, the lockdown experience is likely to be dire. In addition, there have been further limitations placed on these children, given that they could not play outside or see their same-age peers.

\section{Impacts of the lockdown(s) and school closure(s) on children Learning loss}

Existing research in South Africa shows that children in weaker schools fall increasingly below a threshold of required achievement (Spaull \& Kotze 2015; Van Der Berg, Zuze \& Bridgman 2015). The learning deficits resulting from COVID-19 are likely to further exacerbate this problem and widen overall inequality in South Africa. Furthermore, with an ever-dwindling number of school days left in the year, teachers will be increasingly under pressure to cover an already 'full' curriculum in a fraction of the time. An emerging body of research shows the detrimental effects of a disconnect between curricular expectations and the level of the child (Banerjee \& Duflo 2011; Pritchett \& Beatty 2013). In the South African context, how much can teachers adjust the level at which they teach to the new reality of children who have missed up to $40 \%$ of the school year? How much of the curriculum can be excluded in any one grade without affecting children's readiness for the subsequent grades and the expectations of further study?

Apart from the fact that parents and caregivers are not trained or equipped to teach their own children, the existing lockdown 'plans' for learning have not significantly mitigated the losses in learning for children that do not have proper technology-enabled learning at home. At most, $5-10 \%$ of learners can continue learning at home given their access to computers and the internet. Data from TIMSS 2015 (Grade 9) show that for no-fee schools (the poorest 75\%), less than half of children in a given class have a computer with internet access. Only in the wealthiest $5 \%$ of schools do at least $90 \%$ of learners have access to a computer and the internet at home (Gustafsson 2020a).

The DBE's partnership with the South African Broadcasting Corporation (SABC) to provide 'COVID-19 Learner Support' via television and radio (DBE 2020b), whilst admirable, is not a replacement for school. It targets only 'Grade 10-12 and 
ECD' (early childhood development) and is only available for $1.5 \mathrm{~h}$ per day across three television channels. Given that these programs would need to be subject- and grade-specific for students to continue with curricular work, this still amounts to less than $5 \%$ of the 'instruction' time learners would be receiving if they were in school, assuming they watch all the programs dedicated to their grade. It is also not clear what children in Grades R-9 are meant to do.

Access to computers and the internet in South African homes is very low. The General Household Survey of 2018 shows that only $22 \%$ of households have a computer (StatsSA 2019a:63) and only 10\% of respondents have an internet connection in their home (p. 57). Whilst it is true that $90 \%+$ of South African households report access to a mobile phone (p. 56), only $60 \%$ report access to the internet via their mobile phone. It should further be emphasised that these rates are for adults in the household. One cannot assume that during lockdown, children in a household would have exclusive or unlimited access to the cell phone to access educational content. There is also the issue of multiple children in the same household needing to share a mobile phone, and the high cost of data, although there are now some free educational sites (Duncan-Williams 2020).

Some very recent modelling by Gustafsson and Nuga (2020:13) (before schools closed for the additional month of August) suggests that school closures will have severe longterm consequences for learning outcomes in the country. They conclude that:

COVID-19 can erode the learning gains made in schools over the last two decades. As the poor will be most affected, inequality in education could widen with social and economic implications in the long term. (p. 13)

And furthermore that 'without catching up, the skills of Grade 12 graduates would be lower than in the no-pandemic scenario up to $2031^{\prime}$. This is partly because:

$[A]$ ctual learning losses suffered by children due to disruptions such as school closures can be considered to be higher than those attributed to the number of days schools are closed. (p. 13)

Given that most children will have lost $40 \%$ of scheduled school days in 2020 (see Appendix 1), this would amount to approximately half of the years learning being lost using their assumptions.

\section{Economic effects, nutrition and immunisations}

The wider social and economic impacts of the lockdown and the pandemic are also likely to have knock-on effects to children and their schooling. We choose not to summarise that evidence here since it is well documented elsewhere; see Spaull et al. (2020) for a summary of the National Income Dynamics Study Coronavirus Rapid Mobile Survey, NIDSCRAM. That survey showed that approximately 3 million South Africans lost their jobs between February and April 2020, with 2 million job losses experienced by women.
Furthermore, 4.5 million individuals lost all labour-market income as a result of job loss or furlough. This has profound impacts on household welfare and hunger in particular; $47 \%$ of respondents indicated that their household had run out of money to buy food, $22 \%$ said that someone in the household went hungry in the last 7 days, and 15\% reported that a child went hungry in the last 7 days (Spaull et al. 2020). Focussing specifically on child hunger, Van der Berg et al. (2020) argue that 'There has been a sharp increase in child hunger from $8 \%$ of households in 2018 to $15 \%$ in 2020'. The fact that schools were closed over this period and that 9 million children who normally receive free school meals did not receive those meals is a likely contributor to this rise in child hunger.

Since the widespread lockdowns in response to COVID-19, there has been increasing evidence of disruptions to routine childhood immunisation services globally, with more than 68 countries reporting moderate to severe or even total suspension of such services (WHO 2020). This is in line with a systematic review of articles on the indirect health effects of the Ebola virus outbreak in West Africa that showed substantial short- and long-term effects on health services, including declines in caesarean sections and facility-based deliveries and in utilisation of antenatal, postnatal, family planning and children's health services (Brolin Ribacke et al. 2016).

In South Africa, too, some members of the medical community have tried to highlight the effect of the focus on COVID-19 on other health services. The public's fear of contracting the coronavirus may have led to children not being immunised, pregnant mothers avoiding antenatal care appointments and many patients with chronic comorbidities not presenting for treatment or not collecting needed medications ('Greater crisis' looms: 38 doctors plea for non-COVID health care resources, 2020). Amongst children under 5 years of age, three conditions make up $50 \%-60 \%$ of non-neonatal deaths: pneumonia, diarrhoea and HIV/AIDS (Nannan et al. 2019:482). All three of these require prompt medical services to avoid severe illness and deaths. Given the very low mortality of COVID-19 amongst children, it is extremely probable that excess and avoidable deaths from these three illnesses will outweigh COVID-19 deaths amongst children. Furthermore, the Department of Health reports that there has been a 30\% decline in measles vaccinations in April 2020 compared to April last year (Baleta 2020). Measles is six times more infectious than COVID-19 and far more deadly. A widespread pharmacy chain (Dischem) reported a $40 \%$ decline in immunisations in June across their 290 clinics (Baleta 2020).

Of particular concern in South Africa is the high prevalence of HIV and tuberculosis. Any decline in the rates of testing and treatment of these pernicious diseases is likely to have significant long-term consequences. Already the National Institute of Communicable Diseases (NICD) has reported that 'The COVID-19 level 5 restrictions have resulted in an approximately $48 \%$ average weekly decrease in tuberculosis Xpert testing volumes' (NICD 2020b:6). 


\section{Mental health}

Large-scale disasters, such as terrorist attacks, mass shootings or natural disasters '... are almost always accompanied by increases in depression, posttraumatic stress disorder (PTSD), substance use disorder, a broad range of other mental and behavioural disorders, domestic violence, and child abuse' (Galea, Merchant \& Lurie 2020). This was also the case with the SARS epidemic in the countries that it affected. It is therefore quite likely that following the pandemic there will be increases in anxiety and depression, substance abuse, loneliness, domestic violence and child abuse (Soland et al., 2020).

A recent study of 1784 children in Grades 2 to 6 in Hubei Province in China, when schools had been closed as a result of the pandemic for over a month, found that $23 \%$ reported depression symptoms and $19 \%$ had anxiety symptoms (Xie et al. 2020). Depression was more common amongst children who were worried about being affected by the virus.

Recent surveys by Save the Children in the United States, Spain, the United Kingdom, Finland, Germany, Nicaragua and Indonesia led them to conclude that almost one-quarter of children affected by lockdowns and school closures have feelings of anxiety, and that many are at risk of lasting psychological distress, including depression (Radesky 2020). Similarly, Lee (2020) argues that 'School routines are important coping mechanisms for young people with mental health issues. When schools are closed, they lose an anchor in life and their symptoms could relapse'.

Drawing from other situations, such as the effect of Hurricane Katrina, Soland et al. (2020) note that children may face greater food insecurity, loss of family income, loss of family members to the virus, and fear of being infected themselves. The return to school may therefore not be easy for all children. Some would have trouble concentrating and would manifest symptoms of depression and acute anxiety. It is essential to try to understand these impacts and support children's social and emotional needs after the disruption of the pandemic and the lockdown.

An especially pertinent recent systematic review on the psychological impact of quarantine-type situations has found that it led to high levels of post-traumatic stress (29\% to 34\%) and fear (20\%), whilst also increasing depression, low mood, irritability, insomnia, anger and emotional exhaustion (Fegert et al. 2020).

Increased financial stress during economic recessions is also associated with increase in domestic violence. The added complications of the lockdown and permanent presence of children in the home increases the likelihood of children falling victim to such behaviour. As Fegert et al. (2020) state:

[The lockdown phases] of the current COVID-19 pandemic represent a dangerous accumulation of risk factors for mental health problems in children and adolescents of enormous proportions: re-organization of family life, massive stress, fear of death of relatives, especially with relation to grandparents and great-grandparents, economic crisis with simultaneous loss of almost all support systems and opportunities for evasion in everyday life, limited access to health services as well as a lack of social stabilization and control from peer groups, teachers at school, and sport activities. (p. 1)

The Human Sciences Research Council (HSRC) and a University of Johannesburg team analysed the mental health consequences of the lockdown for adults in South Africa, based on an online survey. They derived two latent variables from the responses they obtained about the emotions people felt. The one they termed psychological distress (including stress, being scared, irritability, feeling depressed, sadness, anger) and the other isolation (boredom and loneliness). Further investigation found that the components of psychological distress are higher amongst individuals that reported feeling hunger. The strong presence of this emotion in the contexts of hunger, and its association with psychological distress, is something that children are also likely to experience (Orkin et al. 2020).

\section{Home alone: The extent to which children are left home alone when caregivers return to work and schools remain closed}

Reviewing the South African media discourse on the 'postlockdown' regulations, one of the aspects that has been most neglected is the unintended consequences of re-opening the economy whilst schools and crèches remain closed for most children.

Using data from the Quarterly Labour Force Survey (QLFS) of StatsSA for the 4th quarter of 2019 (StatsSA 2020), it is possible to determine how many schoolchildren, preschoolers and toddlers would be at home with or without an adult caretaker, if everyone who had jobs at the end of 2019 were again to return to work. Table 2 shows that 3.3 million children (18\% of all children in this age group) were in households where there was no additional adult caregiver apart from employed adults. In the remaining $82 \%$ of

TABLE 2: Number of children aged 0 to 18 at home with or without an adult caretaker in the household if all employed people were to be back at work.

\begin{tabular}{lccc}
\hline & $\begin{array}{c}\text { Children with a } \\
\text { caretaker at home }\end{array}$ & $\begin{array}{c}\text { Children with no } \\
\text { caretaker at home }\end{array}$ & $\begin{array}{c}\text { Percentage with no } \\
\text { caretaker (\%) }\end{array}$ \\
\hline Western Cape & 1315712 & 562859 & 30 \\
Eastern Cape & 2207130 & 341025 & 13 \\
Northern Cape & 332266 & 63860 & 16 \\
Free State & 673526 & 168521 & 20 \\
KwaZulu-Natal & 3460694 & 495896 & 13 \\
North West & 1070441 & 211184 & 16 \\
Gauteng & 2809828 & 891763 & 24 \\
Mpumalanga & 1274182 & 249008 & 16 \\
Limpopo & 1837844 & 315074 & 15 \\
South Africa & 14981623 & 3299190 & 18 \\
Non-Metropolitan & 10244619 & 1735737 & 14 \\
Metropolitan & 4737004 & 1563453 & 25 \\
\hline Source Statsics &
\end{tabular}

Source: Statistics South Africa (StatsSA), 2020, Quarterly labour force survey (QLFS) - Q4: 2019, StatsSA, Pretoria. 
households, there would still be an adult available to act as caretaker, especially in extended families. As one would expect, proportionately the number of children without a caretaker would be largest in metropolitan areas, where this ratio is $25 \%$. The biggest proportion of children would be affected in the Western Cape (30\%) and Gauteng (24\%).

One can further estimate these ratios allowing for older siblings ( 15 or above) who might be able to act as caretakers. Whilst that reduces the numbers, the basic problem remains. Even if one includes household members that are 15 years and older as possible caretakers, there would still be 2.3 million children aged $0-15$ years that could be home alone if their employed caregivers returned to work and their school grade or their ECD centre or crèche remained closed. Furthermore, if there were 30\% job losses from the pandemic (leaving more adults at home to care for children), there would still be 1.8 million children aged 18 or below that would be left home alone because their only caregivers would be at work, or 1.2 million if 15 year olds can act as caretakers (see Van der Berg \& Spaull 2020 for more detail).

Perhaps the most severe instance of this would be the care of very young children, that is, those under the age of 6 years. Our analysis shows that if all employed workers return to work, there would be almost 1 million (974 000) children below the age of six who would be left alone in households without an adult caretaker. Whilst it is true that parents and caregivers would try and make some arrangements for members of other households to take care of their children, many caregivers may not have the networks needed, and may feel compelled to go to work to earn income to support their children. This is all because community-based ECD centres and preschools are still not allowed to operate despite the economy re-opening.

In addition to the above, given that most ECD facilities in South Africa are primarily privately operated small businesses, it is unclear how many of these ECD centres and crèches would have been able to survive the income loss of the extended lockdown (see Ilifa Labantwana 2020 for an indication of this).

\section{Conclusion and policy recommendations}

After reviewing the evidence presented in this paper, it is our view that keeping children out of school is not in their best interests. Furthermore, the evidence that exists on schoollevel cases indicates that teachers are not at higher risk compared to the rest of the public, and where schools were open and students were attending school there is no evidence of outbreaks amongst either students or teachers. Given the fact that there are profound costs to children across a number of dimensions, and that the vast majority of the local and international evidence shows that schools are not sites of rapid transmission, all children should return to schools, crèches and ECD centres without any further delay. The extraordinary costs borne by small children and families as a result of the ongoing nationwide lockdowns and school closures will be felt for at least the next 10 years.

When the new coronavirus rapidly spread across the globe, the impact of the virus on children was still unclear, and closing schools from an abundance of caution seemed the responsible thing to do. But much has been learnt since about both COVID-19 and about the effects of lockdown and school closures, both in South Africa and internationally. Given the large social and economic costs of hard lockdowns and wholesale school closures, we would strongly caution against future nationwide lockdowns or school closures, even in the presence of a surge in COVID-19 infections. Policy-makers and government leaders have an obligation to weigh up the costs and collateral damage of their policies, particularly for those who are most vulnerable, such as small children, the elderly and those in poverty.

Millions of South African children's education and mental health have been compromised in this initial period of uncertainty and have continued to be compromised as a result of the rolling school closures. Given what is now known about the mortality rates of COVID-19, and the patterns of infection, we believe that the ongoing disruptions to children's care, education and health are no longer justified.

\section{Acknowledgements Competing interests}

The authors have declared that no competing interests exist.

\section{Authors' contributions}

All authors contributed equally to this work.

\section{Ethical consideration}

The authors confirm that ethical clearance was not required for the study.

\section{Funding information}

The authors received funding from the Allan Gray Orbis Foundation Endowment, the FEM Education Foundation and the Michael \& Susan Dell Foundation.

\section{Data availability statement}

Data sharing is not applicable to this article as no new data were created or analysed in this study.

\section{Disclaimer}

The views and opinions expressed in this article are those of the authors and do not necessarily reflect the official policy or position of any affiliated agency of the authors. 


\section{References}

ASA, 2020, Department of Health Covid modelling symposium, Actuarial Society of South Africa (Online), viewed 12 June 2020, from https://www.spotlightnsp.co. za/wp-content/uploads/2020/05/DOH-Model-symposium-ASSA-20200521.pdf.

Baleta, A., 2020, Dramatic drop in SA's immunization rates, Spotlight (Online), viewed 04 August 2020 from https://www.spotlightnsp.co.za/2020/06/24/dramaticdrop-in-sas-immunisation-rates/.

Bamford, J., McKerrow, N., Barron, P. \& Aung, Y., 2018, 'Child mortality in South Africa: Fewer deaths, but better data are needed', South African Medical Journal 108(Suppl 3), S25-S32. https://doi.org/10.7196/SAMJ.2018.v108i3.12779

Banerjee, A.V. \& Duflo, E., 2011, Poor economics: A radical rethining of the way to fight global poverty, Public Affairs, New York, NY.

Boast, A., Munro, A. \& Goldstein, H., 2020, 'An evidence summary of Paediatric COVID-19 literature', https://doi.org/10.31440/DFTB.24063

Brolin Ribacke, K., Saulnier, D., Eriksson, A. \& Von Schreeb, J., 2016, 'Effects of the West Africa Ebola virus disease on health-care utilization - A systematic review', Frontiers in Public Health 4(222), 1-12. https://doi.org/10.3389/fpubh.2016.00222

Child, K., 2020, 'More than 40,000 deaths predicted: Behind SA's Covid-19 models', Financial Mail (Online), viewed 12 June 2020, from https://www.businesslive. co.za/fm/features/2020-05-20-more-than-40000-deaths-predicted-behind-sascovid-19-models/.

Davis, R., 2020, 'Latest Covid-19 projections suggest SA cases could total three million', Daily Maverick (Online), viewed 12 June 2020, from https://www.dailymaverick. co.za/article/2020-05-22-latest-covid-19-projections-suggest-sa-cases-couldtotal-three-million/\#gsc.tab=0.

DBE, 2013, Education Management Information System (EMIS), Department of Education, South Africa.

DBE, 2018, School monitoring survey 2017-18-Technical report, Department of Basic Education, Pretoria.

DBE, 2020a, Department of Basic Education Notice 304 of 2020 Disaster Management Act 2020, Government Gazette 43381, 1 June 2020 (Online), viewed 12 June 2020, from https://www.gov.za/sites/default/files/gcis document/ 12 June 2020, from https:

DBE, 2020b, Basic education and SABC launch Coronavirus COVID-19 TV and radio curriculum support programmes for learners, viewed 13 September 2020 from https://www.gov.za/speeches/basic-education-and-sabc $\%$ C2 $\%$ AOlaunch $\% \mathrm{C} 2 \% \mathrm{~A}$ https://www.gov.za/speeches/basic-education-and-sabc
Ocoronavirus-covid-19-tv-and-radio-curriculum-support

DBE, 2020c, School Calendar (Online), viewed 04 August 2020, from https://www.gov. za/about-sa/school-calendar.

Duncan-Williams, K., 2020, 19 April, 'South Africa's digital divide detrimental to the youth', Mail \& Guardian, viewed 13 September 2020, from https://mg.co.za/ article/2020-04-19-south-africas-digital-divide-detrimental-to-the-youth/.

Fegert, J., Vitiello, B., Plener, P. \& Clemens, V., 2020, 'Challenges and burden of the Coronavirus 2019 (COVID-19) pandemic for child and adolescent mental health: A narrative review to highlight clinical and research needs in the acute phase and the long return to normality', Child and Adolescent Psychiatry and Mental Health the long return to normality', Child and Adolescent Psych
14, 20. https://doi.org/10.1186/s13034-020-00329-3

Galea, S., Merchant, R.M. \& Lurie, N., 2020, 'The mental health consequences of COVID-19 and physical distancing: The need for prevention and early intervention', JAMA Internal Medicine 80(6), 817-818. https://doi.org/10.1001/jamainternmed. JAMA Internal 2020.1562

Gustafsson, M., 2020, Patterns in the COVID-19 cases among learners and staff in Gauteng schools: Analaysis of school-level data to 8 July, Department of Basic Education (Online), viewed 07 August 2020, from https://www.education.gov.za/ Portals/0/Documents/Reports/Gauteng\%208\%20July\%20infections $\% 20$ patterns $\% 202020 \% 2007 \% 2021$.pdf?ver=2020-07-28-165203-553.

Gustafsson, M. \& Nuga, C., 2020, How is the COVID-19 pandemic affecting educational quality in South Africa? Evidence to date and future risks, Coronavirus rapid mobile survey insight brief (Online), viewed 04 August 2020, from https:// cramsurvey.org/wp-content/uploads/2020/07/Gustafsson.-Nuga.-How-is-theCOVID-19-pandemic-affecting-educational-quality-in-South-Africa_-1.pdf

Hall, K., 2019, 'Income poverty, unemployment and social grants', in M. Shung-King, L. Lake, D. Sanders \& M. Hendricks (eds.), South African Child Gauge 2019, Children's Institute, University of Cape Town, Cape Town.

Ilifa Labantwana, 2020, The plight of the ECD workforce: An urgent call for relief in the wake of COVID-19 (Online), viewed 07 August 2020, from https://ilifalabantwana. co.za/wp-content/uploads/2020/04/Final-report-The-plight-of-the-ECDworkforce.pdf.

International Diabetes Federation, 2019, IDF Diabetes atlas, viewed 13 June 2020 from https://www.diabetesatlas.org/en/

KCRW Berlin, 2020, 10 August, Berlin students back in the classroom amid uncertainty about a second coronavirus wave (Online), viewed 10 August 2020, from https:// kcrwberlin.com/2020/08/berlin-students-back-in-the-classroom-amid uncertainty-about-a-second-coronavirus-wave/.

Lee, J., 2020, June, 'Mental health effects of school closures during CoVID-19', The LANCET Child \& Adolescent Health 4(6), 421. https://doi.org/10.1016/S2352 4642(20)30109-7

Mendelsohn, M., Madhi, S., Nel, J. \& Venter, F., 2020, 'Stop random Covid-19 testing and sort out the backlog', Daily Maverick, 1 June 2020 (Online), viewed 12 June 2020, from https://www.dailymaverick.co.za/article/2020-06-01-urgent-stoprandom-covid-19-testing-and-sort-out-the-backlog/.
Mitchley, A., 2020, 'Majority of Covid-19 related deaths in Gauteng suffered from hypertension or diabetes', News24 (Online), viewed 02 August 2020, from https:// www.news 24 .com/news24/southafrica/news/majority-of-covid-19-relateddeaths-in-gauteng-suffered-from-hypertension-or-diabetes-20200730.

Motshekga, A., 2020, State of readiness for the reopening of schools, Department of Basic Education (Online), viewed 13 June 2020, from https://www.gov.za/ speeches/minister-angie-motshekga-state-readiness-reopening-schools-7jun-2020-0000.

Mthethwa, A., 2020, 'Living in fear: The plight of educators with comorbidities', Daily Maverick (Online), viewed 02 August 2020, from https://www.dailymaverick. co.za/article/2020-07-07-living-in-fear-the-plight-of-educators-withcomorbidities/\#gsc.tab=0.

Nannan, N., Groenewald, P., Pillay-Van Wyk, V., Nicol, E., Msemburi, W., Dorrington, R. et al., 2019, 'Child mortality trends and causes of death in South Africa, 1997-2012, and the importance of a national burden of disease study', South African Medical Journal 109(7), 480-485. https://doi.org/10.7196/SAMJ.2019. v109i7.13717

National Department of Health: Statistics South Africa; South African Medical Research Council; IFC, 2019, South Africa Demographic and Health Survey 2016 Final Report, National Department of Health, Pretoria.

NICD, 2020b, Impact of COVID-19 interventon on TB testing in South Africa, National Institute for Communicable Diseases (Online), viewed 12 June 2020, from https:// www.nicd.ac.za/wp-content/uploads/2020/05/Impact-of-Covid-19interventions-on-TB-testing-in-South-Africa-10-May-2020.pdf.

Orkin, M., Roberts, B., Bohler-Muller, N. \& Alexander, K., 2020, 'The hidden struggle: The mental health effects of the Covid-19 lockdown in South Africa', Daily Maverick, 13 May, viewed 13 September 2020, from https://www.dailymaverick. co.za/article/2020-05-13-the-hidden-struggle-the-mental-health-effects-of-thecovid-19-lockdown-in-south-africa/.

Our World in Data, 2020, Coronavirus: Case fatality rates by age (Online), viewed 10 June 2020, from https://ourworldindata.org/mortality-risk-covid.

Pritchett, L. \& Beatty, A., 2013, The negative consequences of overambitious curriculy in developing countries, Center for Global Development, Washington, DC.

Radesky, J., 2020, May 8, Supporting children's mental health during COVID-19 school closures, NEIJM Journal Watch, viewed 02 June 2020, from https://www.jwatch. org/na51491/2020/05/08/supporting-childrens-mental-health-during-covid-19school.

SA Government, 2008, South African Schools Act 84 of 1996: Call for Comments on National Minimum Uniform Norms and Standards for School Infrastructure, Governement Gazette No. 31616, Notice 1439 of 2008, South African Government, Governement

SAPA, 2020, SAPA statement on COVID-19, South African Paediatric Association (Online), viewed 12 June 2020, from https://www.dailymaverick.co.za/ article/2020-05-31-paediatricians-support-move-to-reopen-schools/\#gsc.tab=0.

Schäfer, D., 2020, Covid-19 in schools - The facts, Western Cape Education Department (Online), viewed 07 August 2020, from https://wcedonline.westerncape.gov.za/ news/covid-19-schools-facts.

Soland, J., Kuhfeld, M., Tarasawa, B., Johnson, A., Ruzek, E. \& Liu, J., 2020, May 27 'The impact of COVID-19 on student achievement and what it may mean for educators', Brown Center Chalkboard viewed 02 June 2020, from https://www. brookings.edu/blog/brown-center-chalkboard/2020/05/27/the-impact-of-covid19-on-student-achievement-and-what-it-may-mean-for-educators/?utm source=feedblitz\&utm medium=FeedBlitzRss\&utm campaign=brookingsrss] topfeeds/brown center_chalkboard

Spaull, N., 2020, 'COVID-19 and schooling in South Africa: Who should go back to school first?', Prospects. https://doi.org/10.1007/s11125-020-09470-5

Spaull, N. \& Kotze, J., 2015, 'Starting behind and staying behind in South Africa: The case of insurmountable learning deficits in mathematics', International Journal of Educational Development 41, 13-24. https://doi.org/10.1016/j.ijedudev. 2015.01.002

Spaull, N., Ardington, C., Bassier, I., Bhorat, H., Bridgman, G., Brophy, T., et al., 2020 NIDS-CRAM synthesis report wave 1: Overview and findings, National income Dynamics Study Coronavirus Rapid Mobile Survey NIDS-CRAM (Online), viewed 07 August 2020, from https://cramsurvey.org/wp-content/uploads/2020/07/ Spaull-et-al.-NIDS-CRAM-Wave-1-Synthesis-Report-Overview-and-Findings-1.pdf.

Spiegelhalter, D., 2020, 'Children at greater risk of lighning strike than coronavirus (Online)', WalesOnline, viewed 12 June 2020, from https://www.walesonline.co. uk/news/uk-news/children-greater-risk-lightning-strike-18393474.

Statistics South Africa (StatsSA), 2016a, Mid-year population estimates 2016 (Online), Statistics South Africa, viewed 09 June 2020, from https://www.statssa.gov.za/ publications/P0302/P03022016.pdf.

Statistics South Africa (StatsSA), 2018a, Marginalised groups indicator report 2018 StatsSA, Pretoria.

Statistics South Africa (StatsSA), 2018b, Mortality and causes of death in South Africa, 2016: Findings from death notification, Statistics South Africa (Online), from https://www.statssa.gov.za/publications/P03093/P030932016.pdf.

Statistics South Africa (StatsSA), 2019a, General household survey 2018, StatsSA, Pretoria.

Statistics South Africa (StatsSA), 2019b, Victims of crime survey 2018/19, StatsSA, Pretoria.

Statistics South Africa (StatsSA), 2020, Quarterly labour force survey (QLFS) - Q4: 2019, StatsSA, Pretoria.

The Children's Act [2005] Act Number 38 of 2005, South Africa, viewed 09 Oct 2020, from https://www.westerncape.gov.za/Text/2010/12/childrens.act.final_ regulations26_jan_2010.pdf 
Van Bruwaene, L., Mustafa, F., Cloete, J., Goga, A. \& Green, R., 2020, 'What are we doing to the children of South Africa under the guise of COVID-19 lockdown?', South African Medical Journal 110(7), 1-2.

Van Der Berg, S., 2015, 'What the annual national assessments can tell us about learning deficits over the education system and the school career', South African Journal of Childhood Education 5(2), 28-43. https://doi.org/10.4102/sajce.v5i2.381

Van Der Berg, S. \& Spaull, N., 2020, 'Counting the Cost: COVID-19 school closures in South Africa and its impact on children', RESEP Working Paper (Online), viewed 02 August 2020, from https://resep.sun.ac.za/wp-content/uploads/2020/06/Vander-Berg-Spaull-2020-Counting-the-Cost-COVID-19-Children-and-Schooling-15June-2020-1.pdf.

Van Der berg, S., Zuze, L. \& Bridgman, G., 2020, The impact of the coronavirus and lockdown on children's welfare in South Africa, National Income Dynamics Study Coronavirus Rapid Mobile Survey (NIDS-CRAM (Online), from https://cramsurvey. org/wp-content/uploads/2020/07/Van-der-Berg_policy-brief.pdf.

Western Cape Department of Health, 2020, Analysis in comorbidities in adult COVID-19 deaths (Online), viewed 02 August 2020, from https://coronavirus. westerncape.gov.za/news/analysis-comorbidities-adult-covid-19-deaths.
Western Cape Government, 2020, Covid-19 Dashboard (Online), viewed 10 June 2020, from https://coronavirus.westerncape.gov.za/covid-19-dashboard.

WHO, 2020a, Coronavirus disease 2019 (COVID-19) Situation Report 51, World Health Organisation (Online), viewed 13 September 2020, from https://www.who.int/ docs/default-source/coronaviruse/situation-reports/20200311-sitrep-51 covid-19.pdf?sfvrsn=1ba62e57_10

WHO, 2020b, At least 80 million children under one at risk of diseases such as diphtheria, measles and polio, as Coronavirus disrupts routine vaccination efforts, warn Gavi, WHO and UNICEF, viewed 10 June 2020, from https://www.who.int/ news-room/detail/22-05-2020-at-least-80-million-children-under-one-at-risk-ofdiseases-such-as-diphtheria-measles-and-polio-as-covid-19-disrupts-routinevaccination-efforts-warn-gavi-who-and-unicef.

WHO, 2020c, Coronavirus disease (COVID-19) advice for the public, World Health Organisation (Online), viewed 13 June 2020, from https://www.who.int/ emergencies/diseases/novel-coronavirus-2019/advice-for-public.

Xie, X., Xue, Q., Zhou, Y., Zhu, K., Liu, Q., Zhang, J. et al., 2020, 'Mental health status among children in home confinement during the coronavirus disease 2019 outbreak in Hubei Province, China', JAMA Pediatrics (Online), 1-2. https://doi. org/10.1001/jamapediatrics.2020.1619 


\section{Appendix 1:}

School days lost due to COVID-19 school closures in South Africa, up to date as of 2 August 2020.

FIGURE 1-A1: School days lost due to COVID-19 in South Africa.

\begin{tabular}{|c|c|c|c|c|}
\hline \multicolumn{5}{|c|}{ School days lost up to 23 August 2020 by grade } \\
\hline & $\begin{array}{l}\text { (New calendar) Current school } \\
\text { days up to } 23 \text { August } 2020\end{array}$ & $\begin{array}{c}\text { (Old calendar) Pre-COVID } \\
\text { scheduled school days up to } 23 \\
\text { August } 2020\end{array}$ & Days lost up to 23 August 2020 & $\begin{array}{l}\text { School days lost as a percentage of } \\
\text { pre-COVID scheduled school days up to } \\
23 \text { August } 2020(\%)\end{array}$ \\
\hline Grade 12 & 106 & 136 & 30 & 22 \\
\hline Grade 7 & 101 & 136 & 35 & 26 \\
\hline All other grades & 48 & 136 & 88 & 65 \\
\hline \multicolumn{5}{|c|}{ School days lost in 2020 by grade (assuming no further closures beyond 23 August 2020) } \\
\hline & $\begin{array}{l}\text { (New calendar) Current school } \\
\text { days in proposed } 2020 \text { calendar }\end{array}$ & $\begin{array}{l}\text { (Old calendar) Pre-COVID } \\
\text { scheduled school days in } 2020\end{array}$ & $\begin{array}{l}\text { Days lost in } 2020 \text { (assuming no } \\
\text { further school closures) }\end{array}$ & $\begin{array}{l}\text { School days lost in } 2020 \text { compared to } \\
\text { pre-COVID scheduled school days in } \\
2020(\%)\end{array}$ \\
\hline Grade 12 & 182 & 204 & 22 & 11 \\
\hline Grade 7 & 177 & 204 & 27 & 13 \\
\hline All other grades & 124 & 204 & 80 & 39 \\
\hline
\end{tabular}

Source: DBE, 2020a, Department of Basic Education Notice 304 of 2020 Disaster Management Act 2020, Government Gazette 43381,1 June 2020 (Online), viewed 12 June 2020, from https:// www.gov.za/sites/default/files/gcis document/202006/43381gen304.pdf; DBE, 2020c, School Calendar (Online), viewed 04 August 2020, from https://www.gov.za/about-sa/school-calendar. 